\title{
Gender and Journal Authorship in Eight Prestigious Political Science Journals
}

\author{
Marijke Breuning, Truman State University \\ Kathryn Sanders, Truman State University
}

$\mathrm{H}$ ow well are women authors represented in the most-recognized journals in political science? To what degree does the presence of women authors mirror women's presence in the discipline? Although a few studies have sought to provide data on the presence of women authors in political science journals (Young 1995; Kelly et al. 1994), more recent work on the visibility of women in the discipline has focused on gender and authorship of edited volumes (Mathews and Andersen 2001), on the participation of women in the APSA annual meetings (e.g., Gruberg 2006; 2004), and on the status of women in the discipline (Sarkees and McGlen 1992; 1999; Committee on the Status of Women in the Profession 2001). All are useful endeavors. This paper analyzes the presence of women authors in six volume years (1999-2004) of eight prestigious political science journalsAmerican Political Science Review (APSR), American Journal of Political Science (AJPS), Journal of Politics $(J O P)$, World Politics (WP), International Organization (IO), Comparative Politics (CP), Comparative Political Studies (CPS), and International Studies Quarterly (ISQ).

\section{Literature}

Although there have been a number of studies that have investigated journal content in political science generally or

\footnotetext{
Marijke Breuning is associate professor of political science at Truman State University. She has published work on foreign policy analysis, foreign aid and development cooperation, and ethnic politics. She has also published on international studies curriculum and other pedagogical subjects. She is currently part of the editorial teams of the Journal of Political Science Education and Foreign Policy Analysis.
}

Kathryn Sanders is a senior majoring in political science at Truman State University. She has presented her research at several conferences and plans to pursue graduate education in communication. in a specific subfield (Kelly et al. 1994; Goldmann 1995; Young 1995; Norris 1997; Waever 1998; Aydinli and Mathews 2000; Bennett et al. 2003; Breuning et al. 2005), only two have investigated specifically the presence of women in political science journals (Kelly et al. 1994; Young 1995). In addition to journal content, a number of quantitative assessments have involved the ranking of political science departments (Garand and Graddy 1999; Hix 2004), the ranking of political science journals (Giles, Mizell, and Patterson 1989; Crewe and Norris 1991; Nisonger 1993; Garand and Giles 2003), or critiques of such rankings (Garand 1990; Lester 1990). Furthermore, there have been some investigations into who publishes. Here, the subject has alternatively been the connection between graduate training and productivity (McCormick and Bernick 1982; Rice et al. 2002), the gender gap in publishing (Mathews and Andersen 2001), and geographically based divides in publishing (Aydinli and Mathews 2000). Although most investigations of the discipline deal with publishing in academic journals, two focused on book publishing (Mathews and Andersen 2001; Rice et al. 2002).
About a decade ago, Young (1995) found that women are better represented in the profession than their work is in its journals. Is this still the case? In this paper, we investigate the relative presence of women authors in eight of the profession's prestigious journals.

\section{Data and Methods}

The selection of the eight journals was guided by the findings of studies that have sought to rank political science journals (Giles et al. 1989; Crewe and Norris 1991; Nisonger 1993; Garand and Giles 2003). ${ }^{1}$ Table 1 provides an overview of the rankings of the eight journals in these studies and also of the focus of each journal's content. Special emphasis was placed on the recent rankings of Garand and Giles (2003) and an effort was also made to include journals that publish work across political science subfields ( $A P S R, A J P S$, and, to some degree, $J O P$ ), as well as journals that tend to focus on a specific subfield, such as international relations (WP, IO, $I S Q)$, comparative politics ( $W P, C P$, $C P S)$, and American politics $(J O P)$. The apparent lesser emphasis on American politics is mitigated by the tendency of both the APSR and AJPS to include

\begin{tabular}{|c|c|c|c|c|c|c|}
\hline & $\begin{array}{l}\text { Subfield } \\
\text { Focus* }\end{array}$ & $\begin{array}{c}\text { Garand } \\
\text { and Giles } \\
(2003)\end{array}$ & $\begin{array}{l}\text { Nisonger } \\
\text { (1993) }\end{array}$ & $\begin{array}{c}\text { Crewe } \\
\text { and Norris } \\
(1991)^{\star \star}\end{array}$ & $\begin{array}{c}\text { Garand } \\
(1990)\end{array}$ & $\begin{array}{l}\text { Giles } \\
\text { et al. } \\
(1989)\end{array}$ \\
\hline APSR & Am, C, IR & 1 & 2 & 3 & 1 & 3 \\
\hline AJPS & Am, C, IR & 2 & 10 & 5 & 3 & 5 \\
\hline JOP & $\mathrm{Am}$ & 3 & 14 & 6 & 2 & 6 \\
\hline$W P$ & C, IR & 4 & 7 & 1 & 4 & 1 \\
\hline 10 & C, IR & 5 & 6 & 8 & 19 & 9 \\
\hline$C P$ & $\mathrm{C}$ & 9 & 29 & 9 & 8 & 10 \\
\hline CPS & C & 11 & 23 & 16 & 22 & 11 \\
\hline$I S Q$ & IR & 14 & 11 & 17 & 23 & 12 \\
\hline
\end{tabular}

*From Table 6, Garand and Giles (2003).

${ }^{* *}$ Ratings by U.S. scholars are presented. Crewe and Norris (1991) also included ratings by UK scholars. 
relatively more articles on American politics' subjects. The selected journals are each prestigious and have a broad impact in the field, not just among scholars in the U.S., but internationally as well. ${ }^{2}$

We employed a systematic content analysis to examine the contents of all issues of these eight journals for the most recent six completed volume years (1999-2004). Following Aydinli and Mathews (2000), Norris (1997), and McCormick and Bernick (1982), we coded research articles and notes, a total of 1,605 items. Since we are interested in data on authorship, we coded each author separately, resulting in an $\mathrm{N}$ of 2,554 .

We recorded the name and affiliation of each author, and noted whether the author's affiliation was an academic institution. If so, we categorized the institution according the Carnegie Classification of Institutions of Higher Education $(2000 ; 2001)$, which classifies American colleges and universities into nine categories. We collapsed these into Research Universities, Master's Colleges and Universities, Baccalaureate Colleges, and Other for our analysis. ${ }^{3}$ For non-U.S. institutions, the first author made an assessment of the institution's most appropriate category on the basis of the university's web site information and consultation with colleagues.

Further, we coded the gender, academic discipline, and academic rank of each author. This information is generally discernable from the "Notes on Contributors" section. ${ }^{4}$ For authors from nonAmerican institutions, we approximated their academic rank by classifying lecturers as assistant professors and senior lecturers as associate professors. Although the specific meanings of academic ranks vary dramatically across state boundaries (and indeed across institutions within a country), these categorizations provide at least a rough estimate of academic seniority. The author's gender was determined on the basis of whether the biographical note referred to the author as "she" or "he." In the few cases where academic rank, academic discipline, or gender could not be determined on the basis of the biographical note, we relied on Internet searches.

Subsequently, we recorded the number of authors for each piece, their rank order, how many among them were women, and the primary methodology of the article. To determine the most appropriate categorization regarding this last variable, we read the abstract, and sometimes the introduction and methods section to determine the most appropriate category for the item's methodology. We looked for a statement by the author regarding the article's methodology, which was especially helpful in the relatively few cases where multiple methods were employed. The author's statement helped us evaluate, e.g., whether the author considered the mathematical model or the statistical test as the core contribution of the item. We coded accordingly. The coding scheme for classifying each item's primary methodology was derived from Norris (1997), although we expanded the categories to create a more detailed classification.

The coding was completed by upperdivision undergraduate students with training in political science methodology. ${ }^{5}$ Any vague, unclear, or missing information was tracked down by the first author, who also reviewed all the coding decisions and checked them against the journal contents. Hence, the final dataset reflects the combined judgment of the coders and the first author for each datapoint.

\section{Findings}

The objective of this investigation is to ascertain the relative presence of women authors in eight prestigious journals in political science. To aid in the interpretation of our findings, we obtained data regarding the proportion of women in both the American Political Science Association (APSA) and the International Studies Association (ISA). Women's membership in the various sections of APSA varies between a low of $19.9 \%$ for political methodology to a high of $92.3 \%$ for women and politics.
On average, women account for $32.2 \%$ of APSA membership (averaged across the section memberships). Women's membership in sections of ISA shows a similar pattern: ranging from $12.1 \%$ for intelligence studies and $18.2 \%$ for scientific study of international processes (a methodologically oriented section) to $81.4 \%$ in feminist theory and gender studies. Overall, $31.8 \%$ of ISA's members are women. ${ }^{6}$

Additional context is provided by Gruberg's (2006) reports on participation by women in the APSA's annual meeting. Gruberg $(2005,113)$ reports that in 1997 (two years prior to the first journal volume year we coded), $27.7 \%$ of the paper givers were women. By 2002, this figure had increased slightly to $28.6 \%$, and in the past two years it has topped $30 \%$. Gruberg's figures indicate that the proportion of women who are actively engaged in scholarship now approximates the proportion of women in both APSA's and ISA's membership.

Women's presence in the eight journals under investigation lags behind these figures, as shown in Table 2. Women make up an average of $20.9 \%$ of the authors if only the first author is considered, and $20.4 \%$ if all authors are considered. The journals differ in their propensity to publish research authored or co-authored by women. Whether we consider first authors only or all authors, research by women is least likely to appear in the APSR (17.7\% and $16.3 \%$, respectively) and most likely to appear in $C P(32.5 \%$ and $31.4 \%$, respectively). The percentage of women authors publishing in $C P$ reflects the percentage of

\section{Table 2 \\ Relative Presence of Women Authors in Each Journal (Research Articles and Notes only)}

\begin{tabular}{|c|c|c|c|c|c|c|}
\hline & \multicolumn{2}{|c|}{ Women (\%) } & \multicolumn{2}{|c|}{ Men (\%) } & \multicolumn{2}{|c|}{ Total (N) } \\
\hline & $\begin{array}{c}\text { 1st } \\
\text { Author }\end{array}$ & $\begin{array}{c}\text { All } \\
\text { Authors }\end{array}$ & $\begin{array}{c}\text { 1st } \\
\text { Author }\end{array}$ & $\begin{array}{c}\text { All } \\
\text { Authors }\end{array}$ & $\begin{array}{c}\text { 1st } \\
\text { Author }\end{array}$ & $\begin{array}{c}\text { All } \\
\text { Authors }\end{array}$ \\
\hline APSR & 17.7 & 16.3 & 82.3 & 83.7 & 232 & 386 \\
\hline AJPS & 17.9 & 18.6 & 82.1 & 81.4 & 296 & 527 \\
\hline$J O P$ & 17.9 & 18.4 & 82.1 & 81.6 & 307 & 571 \\
\hline$W P$ & 28.4 & 26.0 & 71.6 & 74.0 & 88 & 123 \\
\hline 10 & 20.3 & 20.1 & 79.7 & 79.9 & 153 & 219 \\
\hline$C P$ & 32.5 & 31.4 & 67.5 & 68.6 & 123 & 137 \\
\hline CPS & 24.6 & 26.0 & 75.4 & 74.0 & 236 & 335 \\
\hline$I S Q$ & 19.4 & 18.8 & 80.6 & 81.3 & 170 & 256 \\
\hline Overall (\%) & 20.9 & 20.4 & 79.1 & 79.6 & 100 & 100 \\
\hline Overall (N) & 336 & 520 & 1,269 & 2,034 & 1,605 & 2,554 \\
\hline
\end{tabular}

For 1st Author: Chisquare 19.939, df 7, sign .006

For All Authors: Chisquare 25.885, df 7, sign .001 


\section{Table 3 \\ Institutional Affiliation of Authors (Research Articles and Notes only)}

\begin{tabular}{|c|c|c|c|c|c|c|}
\hline & \multicolumn{2}{|c|}{ Women (\%) } & \multicolumn{2}{|c|}{ Men $(\%)$} & \multicolumn{2}{|c|}{ Total (\%) } \\
\hline & $\begin{array}{c}\text { 1st } \\
\text { Author }\end{array}$ & $\begin{array}{c}\text { All } \\
\text { Authors }\end{array}$ & $\begin{array}{c}\text { 1st } \\
\text { Author }\end{array}$ & $\begin{array}{c}\text { All } \\
\text { Authors }\end{array}$ & $\begin{array}{c}\text { 1st } \\
\text { Author }\end{array}$ & $\begin{array}{c}\text { All } \\
\text { Authors }\end{array}$ \\
\hline Research Universities & 90.2 & 88.3 & 89.5 & 89.9 & 89.7 & 89.5 \\
\hline $\begin{array}{l}\text { Masters Colleges and } \\
\text { Universities }\end{array}$ & 3.0 & 2.9 & 3.8 & 3.9 & 3.6 & 3.7 \\
\hline Baccalaureate Colleges & 3.9 & 4.8 & 4.6 & 3.9 & 4.4 & 4.1 \\
\hline Other Academic & .9 & .8 & .3 & .2 & .4 & 3 \\
\hline Non-Academic & 2.1 & 3.3 & 1.8 & 2.1 & 1.9 & 2.3 \\
\hline Overall (N) & 336 & 520 & 1,269 & 2,034 & 1,605 & 2,554 \\
\hline
\end{tabular}

For 1st Author: Chisquare 2.923, df 4, sign .571

For All Authors: Chisquare 8.897, df 4, sign .064 (which are more likely to be employed by women) and rational choice or formal models (which are somewhat more likely to be employed by men). These findings mirror those of Breuning et al.'s (2005) study of international relations journals $(I O, I S Q, W P)$, although the difference between women and men authors is somewhat less pronounced in this study. Additionally, the eight journals differ in their propensity to publish articles that employ statistical analyses: $A J P S$ and $J O P$ strongly emphasize statistics $(75.0 \%$ and $72.0 \%$, respectively), $C P$ much less so $(13.0 \%$ of articles employ statistics). ${ }^{7}$ Interestingly, the journal with the lowest propensity to publish statistically based articles $(C P)$ is also the journal that publishes the largest proportion of articles by women. Conversely, journals with higher proportions of statistical analyses (AJPS and JOP) are less likely to publish work by women.

Journals also differ in their propensity to publish the work of junior scholars.

The APSR is the least likely to publish work by junior scholars: assistant professors account for $33.2 \%$ of first authors and $29.3 \%$ of all authors. Whereas $W P$ and $C P$ publish the highest proportion of work by assistant professors $(54.5 \%$ and $52.0 \%$ of first authors, and $43.9 \%$ and $51.1 \%$ of all authors, respectively). ${ }^{8}$

Over half of all research articles and notes $(55.9 \%)$ are single-authored. Of the single-authored items, three quarters $(77.0 \%)$ are produced by men and one quarter $(23.0 \%)$ by women. Of the $44.1 \%$ of items that are co-authored, almost two-thirds $(63.4 \%)$ are coauthored by teams of two or more men

There are some factors that might explain why women are less present in these eight journals than in the associations (APSA and ISA), including where women are employed, their rank, and/or their methodological approach. We will turn to each of these factors.

The women authors in these journals are not significantly different from men in terms of their institutional affiliation. Table 3 shows that the authors are overwhelmingly affiliated with research-oriented institutions-primarily those classified as "Research I" in the Carnegie Classification of Higher Education (2000; 2001). Women authors have a slightly higher likelihood to be affiliated with specialized or associate's institutions (listed as "Other Academic" in Table 3) or to be employed in a non-academic setting, but the difference is not statistically significant.

Where women and men authors do differ significantly is in their academic methodology. It is employed by just er half of all articles $(54.6 \%$ of first authors) and $61.5 \%$ of all authors. The difference in the proportions of women and men authors who employ statistics is not huge. The difference becomes more obvious when we compare the relative use of case study methods

\begin{tabular}{|c|c|c|c|c|c|c|}
\hline & \multicolumn{2}{|c|}{ Women (\%) } & \multicolumn{2}{|c|}{ Men $(\%)$} & \multicolumn{2}{|c|}{ Total (\%) } \\
\hline & $\begin{array}{l}\text { 1st } \\
\text { Author }\end{array}$ & $\begin{array}{c}\text { All } \\
\text { Authors }\end{array}$ & $\begin{array}{c}\text { 1st } \\
\text { Author }\end{array}$ & $\begin{array}{c}\text { All } \\
\text { Authors }\end{array}$ & $\begin{array}{c}\text { 1st } \\
\text { Author }\end{array}$ & $\begin{array}{c}\text { All } \\
\text { Authors }\end{array}$ \\
\hline Professor & 17.0 & 17.3 & 28.6 & 31.5 & 26.2 & 28.6 \\
\hline Associate Professor & 17.3 & 17.5 & 23.3 & 20.8 & 22.1 & 20.2 \\
\hline Assistant Professor & 52.1 & 45.8 & 38.1 & 34.6 & 41.0 & 36.9 \\
\hline Ph.D. Candidate & 8.0 & 13.1 & 5.1 & 8.0 & 5.7 & 9.0 \\
\hline $\begin{array}{l}\text { Academic/Research, } \\
\text { Postdoc, etc. }\end{array}$ & 3.6 & 3.1 & 3.1 & 2.9 & 3.2 & 3.0 \\
\hline \multirow[t]{2}{*}{ Non-Academic } & 2.1 & 3.3 & 1.8 & 2.1 & 1.9 & 2.3 \\
\hline & 336 & 520 & 1,269 & 2,034 & 1,605 & 2,554 \\
\hline
\end{tabular}

For 1st Author: Chisquare 35.172, df 5, sign .000

For All Authors: Chisquare 59.873, df 5, sign .000 


\begin{tabular}{|c|c|c|c|c|c|c|}
\hline \multirow[b]{2}{*}{ Methodology } & \multicolumn{2}{|c|}{ Women (\%) } & \multicolumn{2}{|c|}{ Men (\%) } & \multicolumn{2}{|c|}{ Total (\%) } \\
\hline & $\begin{array}{c}\text { 1st } \\
\text { Author }\end{array}$ & $\begin{array}{c}\text { All } \\
\text { Authors }\end{array}$ & $\begin{array}{c}\text { 1st } \\
\text { Author }\end{array}$ & $\begin{array}{c}\text { All } \\
\text { Authors }\end{array}$ & $\begin{array}{c}\text { 1st } \\
\text { Author }\end{array}$ & $\begin{array}{c}\text { All } \\
\text { Authors }\end{array}$ \\
\hline Statistical & 50.0 & 57.1 & 55.9 & 62.6 & 54.6 & 61.5 \\
\hline Case Study/Case Studies & 27.7 & 23.5 & 19.0 & 14.2 & 20.8 & 16.1 \\
\hline Rational Choice/Formal Models & 7.4 & 7.3 & 9.1 & 9.5 & 8.7 & 9.1 \\
\hline Critical Analysis/Text Analysis & 5.4 & 3.8 & 5.8 & 4.0 & 5.7 & 4.0 \\
\hline Theory/Conceptual/Political Thought & 5.7 & 4.6 & 5.1 & 3.9 & 5.2 & 4.0 \\
\hline Content Analysis/Quantitative Text Analysis & 2.1 & 3.8 & 1.7 & 4.0 & 1.8 & 4.0 \\
\hline Experiment & 0 & 0.4 & 1.3 & 1.5 & 1.1 & 1.3 \\
\hline Computational Modeling/AI & 0.3 & 0.4 & 1.2 & 1.6 & 1.0 & 1.4 \\
\hline Review of State of Art & 1.5 & 1.0 & 0.9 & 0.6 & 1.0 & 0.7 \\
\hline Total $(N)$ & 336 & 520 & 1,269 & 2,034 & 1,605 & 2,554 \\
\hline
\end{tabular}

For 1st Author: Chisquare 20.15, df 8, sign .010

For All Authors: Chisquare 36.589, df 8, sign .000

and a little over one third $(36.6 \%)$ are co-authored by teams that include one or more women. Of this last category, only 27 (or $1.7 \%$ of all research articles and notes) are produced by teams of two or three women. This replicates Young's (1995) finding that articles coauthored by women are almost nonexistent. In addition, we found that $28.9 \%$ of all research articles and notes had at least one woman author, which is slightly higher than Young's (1995) finding of almost $24 \%$ of items with at least one female author.

\section{Discussion and Conclusion}

The data reflect an end-result that is influenced by a number of intervening factors, among which: women authors' decisions to submit their work, reviewers' judgments, and editors' decisions. These intervening factors are not easily studied. Journal editors do not necessarily track the gender of submitting authors. ${ }^{9}$ When such data are collected and included in annual reports to a journal's editorial board, it is not always preserved when a journal moves to a new editor or editorial team. The limited available data $^{10}$ indicate that neither women's presence in the discipline nor their conference presentations are good predictors of their propensity to submit their work. Of the submissions received at WP during 1999-2004 an average of 23.2\% were authored or co-authored by women, whereas $26 \%$ of all authors published during that period were women. For $I O$, data are available for only one year, 2002 , when $22 \%$ of submissions were from women. Comparing the authorship of one year's submissions with data from six years of journal content is problematic, but it points in the same direction as the more comprehensive data for $W P$. The same holds for $C P S$ and for $I S Q$, where data are available for three years and yield an average of $21 \%$ and $15.4 \%$ of submissions by women, respectively. Again, women fare comparatively well and appear in each journal at somewhat higher rates than their proportion among submitting authors. It is furthermore interesting to note that while $W P$ and $C P S$ tend to publish more work by women authors than $I S Q$ or $I O$, all four exhibit the same pattern.

At first glance, this data suggest that neither reviewers nor journal editors construct roadblocks to women authors. Of course, it is an open question as to whether the partial data reported here are indeed generalizable to the remaining journals. If they are, then the solution would be to encourage women to submit their work. However, it is also quite possible that women do not submit their work precisely because they perceive that their work does not fit the aims and scope of these journals.

The latter explanation has merit. The data show that women authors who did publish in these eight journals are somewhat more likely to employ case studies and slightly less likely to employ statistics or rational choice and formal models. Accordingly, they were more likely to publish their work in journals that publish such work and less likely to be found in journals that stress statistical analysis and/or rational choice and for- mal models. In addition, the journals differ in their propensity to publish the work of junior scholars. Again, women authors, who are more likely to be assistant professors or Ph.D. candidates, are more likely to be found in journals that are more likely to publish the work of junior scholars. Furthermore, these eight journals overwhelmingly publish authors (women and men) who are affiliated with research institutions. Other research has shown that women are less likely to be employed at such institutions and more likely to hold non-tenure track positions (APSA 2002; Sarkees and McGlen 1999; 1992), which may be a reason why the proportion of women authors publishing in these journals lags well behind women's presence in the discipline.

If so, greater visibility for women in the discipline's most prestigious journals depends on how each of these journals defines its aims and scope, its openness to various research methodologies (issues that journal editors can address), and on women's institutional affiliations or career paths (an issue that journal editors cannot address).

The under-representation of women in these eight journals does not necessarily mean that women publish less than their presence in the discipline would lead us to expect. ${ }^{11}$ It does, however, mean that women are less likely to publish in the discipline's most visible journalssomething which is likely to have an impact on their advancement to the more senior ranks. 


\section{Notes}

1. For critiques of these studies, see Garand (1990) and Lester (1990).

2. Our justification for the selection of journals has much in common with Bennett et al. (2003).

3. The Carnegie Classification distinguishes two types of Doctoral/Research Universities, two types of Master's Colleges and Universities, and three types of Baccalaureate Colleges. We collapsed these categories into Research, Master's, and Baccalaureate institutions, which also made it easier to provide comparative assessments of the non-U.S. institutions not classified by the Carnegie Foundation. The classification system also includes Associate's Colleges and Specialized Institutions. We added a category for non-academic authors.

4. For $A J P S$, the oldest year included in the sample (1999) did not include biographical information on authors. Internet searches were used to ascertain the necessary informa- tion on the authors of that volume year of AJPS.

5. The student coders are political science majors in a structured and sequenced program (see Ishiyama and Hartlaub 2003; Breuning et al. 2001). By the end of the sophomore year (and generally no later than the first semester of their junior year), these students have completed American Government, Introduction to International Relations, Political Science Methods, and Introduction to Comparative Politics. In the process, they have also completed at least one project requiring data collection, data entry, and statistical analysis, and one project applying the comparative method. Each project requires a review of the literature. Hence, these students have some familiarity with academic journals

6. The data for APSA section membership are furnished by the APSA. The data for ISA membership were calculated from data provided by the ISA. The figures for both are for 2004 .
7. The remaining journals have the following proportions of articles employing statistica methods, in declining order: CPS $55.1 \%, I S Q$ $51.8 \%$, APSR $45.7 \%$, WP $40.9 \%$, IO $37.9 \%$.

8 . The remaining journals have the following proportions of assistant professor first authors (and all authors in parentheses), in declining order: AJPS $44.9 \%$ (40.0\%), ISQ 44.7\% (41.4\%), IO $39.2 \%(35.6 \%)$, CPS $38.6 \%$ (36.4\%), JOP $35.5 \%$ (32.9\%).

9. The current editors of the eight journals were contacted to request data on submissions by gender.

10. We thank Ilene P. Cohen (WP), Lisa Martin $(I O)$, James Caporaso and Kathy Murray $(C P S)$, and Steve Poe $(I S Q)$ for furnishing the data that permitted us to calculate the percentages reported here.

11. It is possible that women authors publish more often in specialized or "niche" journals, which were not part of this study.

\section{References}

American Political Science Association. 2002. Survey of Political Science Departments. Washington, D.C.: APSA.

Aydinli, Ersel, and Julie Mathews. 2000. "Are the Core and Periphery Irreconcilable? The Curious World of Publishing in Contemporary International Relations." International Studies Perspectives 1: 289-303.

Bennett, Andrew, Aharon Barth, and Kenneth R. Rutherford. 2003. "Do We Preach What We Practice? A Survey of Methods in Political Science Journals and Curricula." PS: Political Science and Politics 36: 373-8.

Breuning, Marijke, Joseph Bredehoft, and Eugene Walton. 2005. "Promise and Performance: An Evaluation of Journals in International Relations." International Studies Perspectives 6: 447-61.

Breuning, Marijke, Paul Parker, and John T. Ishiyama. 2001. "The Last Laugh: Skill Building through a Liberal Arts Political Science Curriculum." PS: Political Science and Politics 34: 657-61.

Carnegie Foundation for the Advancement of Teaching. 2000. Carnegie Classification of Institutions of Higher Education. Previously available at www.carnegiefoundation.org/ Classification/CIHE2000. For paper copy, see next cite.

2001. The Carnegie Classification of Institutions of Higher Education, $2000 \mathrm{ed}$. Menlo Park, CA: Carnegie Foundation for the Advancement of Teaching.

Committee on the Status of Women in the Profession. 2001. "The Status of Women in Political Science: Female Participation in the Professoriate and the Study of Women and Politics in the Discipline." PS: Political Science and Politics 34: 319-26.

Crewe, Ivor, and Pippa Norris. 1991. "British and American Journal Evaluation: Divergence or Convergence?" PS: Political Science and Politics 24: 524-31.

Garand, James. 1990. "An Alternative Interpretation of Recent Political Science Journal Evaluations." PS: Political Science and Politics 23: 448-51.

Garand, James, and Michael W. Giles. 2003. "Journals in the Discipline: A Report on a New Survey of American Political Scientists." PS: Political Science and Politics 36: 293-308.

Garand, James, and Kristy L. Graddy. 1999. "Ranking Political Science Departments: Do Publications Matter?" PS: Political Science and Politics 32: 113-6.

Giles, Michael W., Francie Mizell, and David Patterson. 1989. "Political Scientists' Journal Evaluations Revisited." PS: Political Science and Politics 22: 613-7.

Goldmann, Kjell. 1995. "Im Westen Nichts Neues: Seven International Relations Journals in 1972 and 1992." European Journal of International Relations 1: 245-58.

Gruberg, Martin. 2004. "Participation by Women in the 2003 APSA Meeting." PS: Political Science and Politics 37: 115-6. - 2005. "Participation by Women in the 2004 APSA Meeting." PS: Political Science and Politics 38: 113-4.

2006. "Participation by Women in the 2005 APSA Annual Meeting." PS: Political Science and Politics 39: 111-2.

Hix, Simon. 2004. "A Global Ranking of Political Science Departments." Working Paper. Available at http://personal.lse.ac.uk/hix/ WorkingPapers.HTM

Ishiyama, John, and Stephen Hartlaub. 2003. "Sequential or Flexible? The Impact of Differently Structured Political Science Majors on the Development of Students Reasoning." PS: Political Science and Politics 36: 83-6.

Kelly, Rita Mae, Linda M. Williams, and Kimberly Fisher. 1994. "Women \& Politics: An Assessment of Its Role Within the Disci- pline of Political Science." Women \& Politics 14: 3-18.

Lester, James. 1990. "Evaluating the Evaluators: Accrediting Knowledge and the Ranking of Political Science Journals." PS: Political Science and Politics 23: 445-7.

Mathews, A. Lanathea, and Kristi Andersen. 2001. "A Gender Gap in Publishing? Women's Representation in Edited Political Science Books." PS: Political Science and Politics 34: 143-7.

McCormick, James, and E. Lee Bernick. 1982. "Graduate Training and Productivity: A Look At Who Publishes." Journal of Politics 44: 212-27.

Nisonger, Thomas E. 1993. "A Ranking of Political Science Journals Based on Citation Data." Serials Review 19: 7-14.

Norris, Pippa. 1997. "Towards a More Cosmopolitan Political Science?” European Journal of Political Research 31: 17-34.

Rice, Tom W., James M. McCormick, and Benjamin D. Bergmann. 2002. "Graduate Training, Current Affiliation, and Publishing Books in Political Science." PS: Political Science and Politics 35: 751-5.

Sarkees, Meredith Reid, and Nancy E. McGlen. 1999. "Misdirected Backlash: The Evolving Nature of Academia and the Status of Women in Political Science." PS: Political Science and Politics 32: 100-8.

. 1992. "Confronting Barriers: The Status of Women in Political Science." Women and Politics 12: 43-86.

Young, Cheryl D. 1995. "An Assessment of Articles Published by Women in 15 Top Political Science Journals." PS: Political Science and Politics 28: 525-33.

Waever, Ole. 1998. "The Sociology of a Not So International Discipline: American and European Developments in International Relations." International Organization 52: 687-727. 